\title{
PEMBUATAN APOTIK HIDUP PENGEMBANGAN KETAHANAN PANGAN PADA SITUASI COVID-19
}

\author{
Suparman ${ }^{1 *}$ \\ Gita Srihidayati ${ }^{2}$ \\ Nurhesti Asr ${ }^{3}$ \\ Indar Yanti ${ }^{4}$ \\ 1,2,3,4Universitas Cokroaminoto Palopo, Palopo, Indonesia \\ suparman@uncp.ac.id $1^{*}$ ) \\ gitasrihidayati@uncp.ac.id ${ }^{2}$ \\ nurhestiasri10@gmail.com $\left.{ }^{3}\right)$ \\ indaryanti117@gmail.com ${ }^{4}$ )
}

Kata Kunci: [Apotik

hidup; Protokol

kesehatan]

Published by:

\begin{abstract}
Abstrak: Tujuan pelaksanaan program pembuatan apotik hidup pengembangan ketahanan pangan pada situasi covid-19 adalah untuk pengembangan ketahanan pangan khususnya di Desa Olang Kecamatan Ponrang Selatan Kabupaten Luwu dan tanaman apotik hidup dalam kehidupan manusia sebagai alternatif untuk sumber pengobatan yang sangat bermanfaat. Metode pelaksanaan dilakukan dengan dua metode yaitu obsevasi dan musyawarah dengan empat tahapan yaitu; tahap perencanaan, tahap persiapan, tahap pelaksanaan, dan tahap pelaporan. Apotik hidup merupakan kegiatan menanam tumbuhan berkhasiat obat yang sangat bermanfaat karena dapat menjadi sumber dalam pemeliharaan kesehatan dan menjadi alternatif dalam pengobatan. Tanaman apotik hidup yang telah ditanam adalah tanaman obat-obatan dan tanaman sayur-sayuran. Tanaman obat yang ditanam diantaranya; kumis kucing, temulawak, kunyit, daun miana, lidah buaya, dan daun paccakke. Tanaman sayur-sayuran yang ditanam bersama tanaman obat diantaranya; tomat, bayam, lombok, terong, dan daun kelor. Selama pelaksanaan kegiatan kuliah kerja nyata tematik.
\end{abstract}

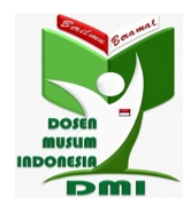

Copyright (C) 2021 The Author(s)

This article is licensed under CC BY 4.0 License

\section{(cc) $\mathrm{BY}$}

https://dmi-journals.org/jai/ 


\section{Pendahuluan}

Covid-19 yang mulai masuk di Indonesia pada awal tahun 2020 dan belum diketahui kapan berakhir menyebabkan pendapatan masyarakat menurun karena adanya beberapa aturan yang dikeluarkan oleh pemerintah untuk mencegah penyebaran covid19. Setelah melakukan observasi dilihat keadaan masyarakat yang kurang mengembangkan tanaman obat-obatan dan sayur-sayuran. Oleh karena itu, masyarakat perlu melakukan pengembangan ketahanan pangan di daerahnya sendiri agar tidak mengalami kekurangan pangan meskipun masih dalam kondisi pandemi. Untuk mengatasi permasalahan tersebut diberikan solusi untuk melakukan pembuatan apotik hidup.

Daerah yang menjadi lokasi dilaksanakan di Desa Olang Kecamatan Ponrang Selatan Kabupaten Luwu. Tema khusus yang dipilih adalah "Ketahanan Pangan" dengan judul "Pembuatan Apotik Hidup untuk Pengembangan Ketahanan Pangan pada Situasi Covid-19". Kegiatan pelaksanaan kuliah kerja nyata tematik dilaksanakan secara kelompok yang terdiri dari dua orang mahasiswa dari program studi yang berbeda, yaitu mahasiswa program studi agribisnis dan mahasiswa program studi pendidikan biologi. Waktu pelaksanaan kuliah kerja nyata tematik dimulai dari tanggal 08 Februari sampai 15 Maret 2021.

Menurut Dian Handayani (2020), Infeksi COVID-19 yang disebabkan virus corona baru merupakan suatu pandemik baru dengan penyebaran antar manusia yang sangat cepat. Derajat penyakit dapat bervariasi dari infeksi saluran napas atas hingga ARDS. Diagnosis ditegakkan dengan RT-PCR, hingga saat ini belum ada terapi antivirus khusus dan belum ditemukan vaksin untuk COVID-19. Diperlukan pengembangan mengenai berbagai hal termasuk pencegahan di seluruh dunia.

Menurut Dimas Satriadi (2017), Apotek hidup adalah pemanfaatan sebagian tanah untuk ditanami tanaman obat-obatan untuk keperluan sehari-hari. Apotek hidup biasa disebut dengan tanaman obat keluarga (TOGA) yang hakekatnya merupakan sebidang tanah baik dihalaman rumah, ladang ataupun kebun yang digunakan untuk membudidayakan tanaman yang berkhasiat sebagai obat. Dalam upaya pelayanan kesehatan, ketersediaan obat dalam jenis yang lengkap, jumlah yang cukup, terjamin khasiatnya, dengan biaya yang murah merupakan permasalahan yang sulit dipecahkan.

Tanaman apotik hidup merupakan salah satu jenis tanaman yang bisa berguna dalam kehidupan manusia sebagai alternatif untuk sumber pengobatan. Walaupun memiliki kegunaan yang sangat bermanfaat bagi kehidupan, masih banyak masyarakat yang belum sadar bahwa apotik hidup bisa bermanfaat dengan baik. Kegiatan ini bertujuan untuk menambah kesadaran masyarakat, khususnya masyarakat di Desa Olang Kecamatan Ponrang Selatan Kabupaten Luwu akan manfaat yang dapat diberikan dari tanaman apotik hidup. Umumnya masyarakat malas untuk melakukan penanaman apotik hidup dan memeliharanya.

Terhadap permasalahan tersebut, dapat memberikan memberikan solusi dengan memilih lahan yang lokasinya strategis dan dapat dijamin pemeliharaannya. Dengan demikian pembuatan tanaman apotik hidup ini dapat berguna dan dapat langsung dirasakan manfaatnya untuk seluruh masyarakat yang membutuhkan khususnya yang ada di Desa Olang. Hasil dari program ini diharapkan bisa meningkatkan kesadaran masyarakat akan kebergunaan apotelk hidup untuk kehidupan sehari-hari dan 
mudahnya menanam tanaman dengan memanfaatkan lahan kosong yang ada di halaman rumah.

\section{Metode Pelaksanaan}

Metode pelaksanaan yang dilaksanakan di Desa Olang adalah metode observasi dan musyawarah. Metode observasi dilakukan untuk melihat kondisi daerah lokasi dan musyawarah dilakukan untuk mendapatkan hasil kesepakatan bersama. Setelah melakukan observasi di lokasi dan musyawarah dengan pemerintah daerah dan masyarakat untuk membahas masalah yang dihadapi di Desa Olang Kecamatan Ponrang Selatan Kabupaten Luwu adalah kurangnya kesadaran untuk mengembangkan ketahanan pangan sehingga program membuat apotik hidup untuk mengembangkan ketahanan pangan. Kemudian pelaksanaan dalam kegiatan pengabdian pada masyarakat di Desa Olang Kecamatan Ponrang Selatan Kabupaten Luwu terdiri dari beberapa tahap, yaitu tahap perencanaan, tahap persiapan, tahap pelaksanaan, dan tahap pelaporan.

\section{Hasil dan Pembahasan}

Hasil atau luaran kegiatan yang telah dilaksanakan adalah pembuatan apotik hidup. Apotik hidup merupakan kegiatan menanam tumbuhan berkhasiat obat yang sangat bermanfaat karena dapat menjadi sumber dalam pemeliharaan kesehatan dan menjadi alternatif dalam pengobatan. Tanaman apotik hidup yang telah ditanam adalah tanaman obat-obatan dan tanaman sayur-sayuran. Selama pelaksanaan kegiatan di Desa Olang tetap mematuhi protokol kesehatan 5M (memakai masker, menjaga jarak, mencuci tangan pakai sabun dan air mengalir, menghindari kerumunan, membatasi mobilisasi dan interaksi). Dengan adanya apotik hidup masyarakat di Desa Olang lebih mudah menemukan tanaman obat yang dibutuhkan dan ketahanan pangan dapat lebih meningkat. Sayur-sayuran ditanam bersama tanaman obat agar masyarakat dapat mengurangi pengeluaran pada masa covid-19 dan kesehatan masyarakat lebih terjaga dibandingkan dengan sayur-sayuran yang dibeli di pasar yang tidak diketahui proses pemeliharaannya. Kegiatan pembuatan hidup terlaksana dengan baik sesuai jadwal yang telah ditentukan dan mencapai target yang diinginkan.

Tanaman obat yang ditanam diantaranya; kumis kucing, temulawak, kunyit, daun miana, lidah buaya, dan daun paccakke. Semua tanaman obat ini selalu dibutuhkan masyarakat dan sangat bermanfaat untuk menyembuhkan beberapa macam penyakit. Tanaman sayur-sayuran yang juga ditanam bersama tanaman obat diantaranya; tomat, bayam, Lombok, terong, dan daun kelor. Sayur-sayuran yang ditanam merupakan sayurasayuran yang setiap harinya dikonsumsi masyarakat dan sangat bermanfaat untuk kesehatan tubuh.

Beberapa manfaat tanaman obat yang ditanam adalah sebagai berikut:

\section{Kumis Kucing}

Selain dijadikan tanaman hias, tanaman apotik hidup yang memiliki bentuk menyerupai kumis kucing ini mampu mengobati berbagai macam penyakit seperti buang air besar, masuk angin, radang ginjal, kencing manis, bahkan menurunkan glukosa dalam darah. Cara paling mudah untuk mengambil manfaatnya yaitu dengan cara direbus atau ditumbuk dengan takaran yang sesuai. 


\section{Temulawak}

Jika dilihat sekilas, tanaman obat yang satu ini mirip dengan kunyit. Bedanya terletak di ujung rimpang temulawak yang berwarna oranye. Sejak dahulu, temulawak sudah menjadi rimpang. Seperti yang sudah diketahui bersama, temulawak memiliki manfaat besar bagi kesehatan. Hal ini bisa dilihat dari banyaknya obat herbal yang menggunakan temulawak untuk bahan utama pembuatannya. Berbagai penyakit yang bisa diobati dengan temulawak adalah sakit ginjal, pusing, sulit buang air besar, serta dapat menambah nafsu makan. Temulawak mengandung senyawa kurkumin yang berkhasiat bagi tubuh.

\section{Kunyit}

Kunyit merupakan tanaman herbal yang cukup dicari saat ini. Pasalnya, kunyit dipercaya memiliki kandungan yang bermanfaat untuk kesehatan sehingga cocok digolongkan sebagai tanaman apotik hidup. Kunyit mengandung curcumin, yaitu antioksidan kuat yang bisa menetralisisr radikal bebas sehingga dapat mencegah terjadinya kanker. Beberapa khasiat dari kunyit antara lain; obat diaere, demam, melancarkan haid, mengurangi nyeri haid, melangsingkan badan, menghilangkan bau badan, tifus, usus buntu, memperlancar ASI, amandel, dan lain-lain.

\section{Daun Miana}

Daun miana atau daun iler merupakan tanaman yang sering digunakan untuk menghiasi halaman rumah. Namun ternyata tanaman ini merupakan tanaman obat yang kaya manfaat. Daun miana memiliki warna merah cerah yang menarik, sehingga sering kali ditanam sebagai tanaman hias. Dibalik kecantikan warna dan bentuknya, tanaman ini juga ternyata mampu menyembuhkan berbagai macam penyakit. Manfaat daun miana untuk kesehatan diantarany; mengatasi wasir, membantu mengobati bisul, dapat menyembuhkan demam dan menurunkan panas, meringankan gejala batuk berdahak dan asma, dapat mengatasi gangguan saat menstruasi, mengobati diabetes, dapat mengobati sakit perut dan mulas, bisa mengatasi mata merah, dan mencegah radikal bebas.

\section{Lidah Buaya}

Lidah buaya menjadi tanaman apotik hidup yang memiliki segudang manfaat dan mudah ditemukan. Tidak hanya bermanfaat untuk kecantikan, lidah buaya juga bermanfaat untuk kesehatan. Lidah buaya mampu menangani beragam masalah kesehatan seperti peradangan, meningkatkan kesehatan jantung, menjaga sistem kekebalan tubuh, serta bisa digunakan sebagai sumber nutrisi dan suplemen.

Dari serangkaian tahap kegiatan yang dilakukan di Desa Olang Kecamatan Ponrang Selatan Kabupaten Luwu adalah sebagai berikut:

\section{Tahap Perencanaan}

Penyusunan rencana kegiatan melibatkan pemerintah daerah dan masyarakat di Desa Olang setelah melakukan observasi. Setelah menyusun rencana kegiatan dilanjutkan dengan mengatur jadwal dan pembagian tugas agar kegiatan berjalan dengan baik dan lancar.

2. TahapPersiapan

Pada tahap persiapan ini dilakukan diskusi penentuan lahan tempat pembuatan apotik hidup bersama dengan pemerintah daerah dan masyarakat di Desa Olang. 
Setelah diskusi disepakati lahan tempat pembuatan apotik hidup dibuat di halaman rumah Kepala Desa Olang. Setelah penentuan lahan tempat pembuatan apotik hidup dilanjutkan dengan diskusi penentuan tanaman apotik hidup yang cocok untuk ditanam. Kemudian melakukan pencarian tanaman apotik hidup yang telah ditentukan di halaman rumah masyarakat Desa Olang.

3. Tahap Pelaksanaan

Pelaksanaan program pembuatan apotik hidup dilaksanakan selama dua hari terdiri atas kegiatan pembuatan apotik hidup dan penanaman apotik hidup di halaman rumah Kepala Desa Olang. Setelah penanaman apotik hidup dilakukan pemasangan papan pengenalan apotik hidup agar masyarakat lebih mudah mengetahui lokasi aptik hidup.

\section{Kesimpulan}

Program Pengabdian pada Masyarakat yang telah dilaksanakanan di Desa Olang Kecamatan Ponrang Selatan Kabupaten Luwu adalah pembuatan apotik hidup yang dibuat di halaman rumah Kepala Desa Olang. Selama pelaksanaan kegiatan mahasiswa tetap mematuhi protokol kesehatan. Apotik hidup merupakan kegiatan menanam tumbuhan berkhasiat obat yang sangat bermanfaat karena dapat menjadi sumber dalam pemeliharaan kesehatan dan menjadi alternatif dalam pengobatan. Tanaman apotik hidup yang telah ditanam adalah tanaman obat-obatan dan tanaman sayur-sayuran.

Saran untuk pemerintah daerah, masyarakat khususnya yang ada di Desa Olang Kecamatan Ponrang Selatan Kabupaten Luwu, dan mahasiswa agar tetap mematuhi protokol kesehatan 5M (memakai masker, menjaga jarak, mencuci tangan pakai sabun dan air mengalir, menghindari kerumunan, membatasi mobilisasi dan interaksi) untuk membantu mengurangi penyebaran covid-19 yang belum diketahui kapan berakhir. Kepada masyarakat diharapkan juga untuk lebih rajin memelihara aptik hidup dan menanam tanaman obat disekitaran rumah agar lebih mudah melakukan pengobatan.

\section{Ucapan Terimakasih}

Terimakasih yang sebesar-besarnya kami ucapkan kepada seluruh pihak yang telah ikut andil dalam kegiatan ini.

\section{Referensi}

Dwiloka Bambang, Dkk. 2018, Peranan Daun Kumis Kucing (Orthosiphon stamineus Benth) dalam Mengeliminasi Kandungan Cd dan Pb pada Dada Ayam Broiler. Jurnal Aplikasi Teknologi Pangan. Vol. 7 (4).

Fati Nelzi, Dkk. 2020. Pengaruh Pemberian Ekstrak Daun Miana (Coleus atropurpureus, L) dalam air minum terhadap Performa broiler (The Effect of Miana (Coleus atropurpureus, L) Leaf Extract in drinking water on The Broiler Performance). Jurnal Ilmiah Ilmu-Ilmu Peternakan. Vol. 23 (12).

Handayani Diah, Dkk. 2020. Penyakit Virus Corona 2019. Jurnal Respirologi Indonesia. Vol. 40 (2). 
Kusbiantoro. 2018. Pemanfaatan Kandungan Metabolit Sekunder pada Tanaman Kunyit dalam Mendukung Peningkatan Pendapatan Masyarakat. Jurnal Kultivasi. Vol. 17 (1).

Madyastuti Rini, Dkk. 2020. Aktivitas Diuretik dan Analisa Mineral Urin Perlakuan Ekstrak Tanaman Kumis Kucing (Orthosiphon Stamineus Benth) pada Tikus Jantan. Vol. 8 (2).

Melliawati R. 2018. Potensi Tanaman Lidah Buaya (Aloe Pubescens) Dan Keunikan Kapang Endofit Yang Berasal Dari Jaringannya. Vol. 9 (1).

Perdana Farid, Dkk. 2019. Temulawak Plant (Curcuma Xanthorrhiza Roxb) As A Traditional Medicine. Jurnal Ilmiah Farmako Bahari. Vol. 10 (1).

Satriadi Dimas, Dkk. 2017. Sistem Pakar pada Tanaman Apotek Hidup untuk Pengobatan Alternatif Menggunakan Metode Certainty Factor. Vol. 6 (2).

Silalahi Marina. 2018. Etnofarmakologi Tumbuhan Miana (Coleus Scutellariodes (L.) Benth) pada Masyarakat Halmahera Barat, Maluku Utara. Jurnal Pro-Life. Vol. 5 (2).

Sukma, Dkk. 2019. Peran Kader dalam Pemanfaatan Apotek Hidup Di Desa Karrang Kecamatan Cendana Kabupaten Enrekang. Jurnal ilmiah dan kesehatan. Vol.2 (2). 